\title{
PENGARUH POLA ASUH ORANG TUA TERHADAP SIKAP PEDULI SAMPAH PADA ANAK
}

\author{
Jonherz Stenlly Patalatu* \\ Stefen Deni Besare \\ Pendidikan Guru Sekolah Dasar, Fakultas Keguruan dan Ilmu Pendidikan, Universitas Halmahera \\ Jl. Raya Wari, Wari Ino, Tobelo, Halmahera, Maluku, Indonesia \\ *email: jonherzpatalatu@gmail.com
}

Artikel diterima: 28 November 2019; disetujui: 31 Mei 2020

\begin{abstract}
This study aims to determine whether there is an influence of parenting pattern on the attitude of caring for garbage in children. Researchers conducted a survey of 200 students in grades 4 to 5 in four elementary schools in Central Tobelo District. The results showed a tvalue of 2.669 with a significance level of $0.008(\rho<0.05)$ which means that there is a positive and significant influence of parenting patterns on the attitude of caring for rubbish in children, the amount of influence is based on the R-square value, $3.5 \%$. Thus, parenting has a role in instilling the attitude of caring for garbage in children.
\end{abstract}

Keywords: parenting pattern; caring for garbage; character; parents; children.

\begin{abstract}
Abstrak: Penelitian ini bertujuan untuk mengetahui apakah terdapat pengaruh pola asuh orang tua terhadap sikap peduli sampah pada anak. Peneliti melakukan survei kepada 200 siswa kelas V hingga VI di empat Sekolah Dasar yang ada di Kecamatan Tobelo Tengah. Hasil penelitian menunjukkan nilai t sebesar 2.669 dengan taraf signifikansi $0.008(\rho<0.05)$ yang berarti bahwa terdapat pengaruh positif dan signifikan pola asuh orang tua terhadap sikap peduli sampah pada anak, besarnya pengaruh berdasarkan nilai $\mathrm{R}$ square yakni sebesar 3.5\%. Dengan demikian maka pola asuh memiliki peran dalam menanamkan sikap peduli sampah pada anak.
\end{abstract}

Kata kunci: pola asuh; peduli sampah; karakter; orang tua; anak.

Pendidikan karakter saat ini telah menjadi fondasi dan ruh bagi arah pelaksanaan pendidikan di Indonesia dengan harapan pendidikan tidak saja menghasilkan insan Indonesia yang cerdas secara intelektual melainkan juga memiliki nilai-nilai karakter yang mencerminkan manusia yang berhati baik, berpikiran baik, dan berperilaku baik. Untuk menguatkan pelaksanaan pendidikan karakter maka dikeluarkanlah Peraturan Presiden (Perpres) Nomor 87 Tahun 2017 tentang Penguatan Pendidikan Karakter. Peraturan tersebut menyebutkan bahwa Penguatan Pendidikan Karakter (PPK) adalah gerakan pendidikan di bawah tanggung jawab satuan pendidikan untuk memperkuat karakter peserta didik melalui harmonisasi olah hati, olah rasa, olah pikir, dan olah 
raga dengan pelibatan dan kerja sama antara satuan pendidikan, keluarga dan masyarakat sebagai bagian dari Gerakan Nasional Revolusi Mental (GNRM). Selanjutnya pada Pasal 3 disebutkan bahwa salah satu nilai yang terkandung dalam pendidikan karakter adalah peduli lingkungan. Bagian ini menekankan bahwa manusia dan lingkungan merupakan dua elemen yang saling mempengaruhi. Oleh karena itu, manusia dituntut untuk peduli terhadap keberadaan lingkungan dimana ia hidup.

Kepedulian manusia terhadap lingkungan tampak lewat sikap dan perilaku menjaga lingkungan tetap bersih dan sehat dengan tidak membuang sampah di sembarang tempat (Mifbakhuddin, dkk., 2010). Ketika lingkungan menjadi bersih dan asri maka manusia dapat menikmati kehidupan yang nyaman dan sehat. Inilah dampak resiprokal yang dapat dinikmati. Dengan demikian tidak salah jika kemudian kepedulian terhadap lingkungan menjadi nilai karakter yang harus diinternaliasi oleh setiap individu sehingga menjadi pedoman dalam berperilaku.

Pada dasarnya, pendidikan karakter peduli lingkungan telah diajarkan di lembaga pendidikan terutama sekolah dasar (Mahendra, 2019). Akan tetapi, kenyataan sehari-hari yang penulis amati, masih ada peserta didik yang membuang sampah seperti kertas dan kemasan plastik sisa makanan dan atau minuman di lingkungan sekolah dan lingkungan tempat tinggalnya. Pada area publik/area keramaian juga masih ditemukan banyak sampah kertas, tisu dan plastik yang berserakan. Ini menunjukkan bahwa masyarakat secara komprehensif belum sepenuhnya menginternalisasi sikap peduli lingkungan. Sehingga sikap peduli lingkungan hanya ada sebatas pengetahuan belum sampai pada tahap penerapan atau bersifat aplikatif.

Melihat realita yang ada, maka penulis berasumsi bahwa kurang optimalnya kepedulian masyarakat terhadap lingkungan sekitar disebabkan oleh lemahnya aturan yang berlaku di lingkungan keluarga. Lemahnya aturan tersebut merupakan bias dari lemahnya peran orang tua atau orang tua dengan sengaja mengabaikan perannya sebagai pendidik yang utama bagi anak di lingkungan keluarga. Dalam hal ini orang tua tidak menerapkan aturan yang ketat tentang peduli lingkungan di dalam keluarga atau faktor yang kedua orang tua belum menjadi role model/teladan tentang bagaimana seharusnya sikap dan perilaku peduli lingkungan. Berdasarkan gambaran tersebut maka penelitian ini bertujuan untuk mengetahui apakah terdapat pengaruh pola asuh orang tua terhadap sikap peduli sampah pada anak.

Peran orang tua berkaitan erat dengan pola asuh. Pola asuh menurut Gunarsa (dalam Adawiah, 2017) merupakan rangkaian upaya aktif orang tua dalam melaksanakan perannya sebagai orang tua terhadap anak. Doinita dan Maria (2015) menyatakan bahwa pola asuh merupakan bentuk perilaku tertentu yang dipilih dan digunakan orang tua untuk merawat, membesarkan dan memberikan pendidikan pada anak. Pola asuh orang tua terbagi menjadi tiga jenis, yaitu; pola asuh 
permisif (permissive), pola asuh otoriter (authoritarian), dan pola asuh demokratis (authorative) (Hurlock, 1999).

Berdasarkan ketiga jenis pola asuh inilah telah dilakukan penelitian antara lain oleh Jannah (2012) tentang bentuk pola asuh orang tua dalam menanamkan perilaku moral pada anak usia di kecamatan Ampek Angkek menemukan bahwa ketika orang tua menggunakan bentuk pola asuh otoriter, anak mengalami kesulitan untuk bersosialisasi. Hal ini disebabkan oleh adanya banyak larangan dan aturan yang harus dipatuhi oleh anak, sehingga akhirnya menciptakan perasaan yang cemas, takut, minder, dan rasa kurang menghargai serta rasa kurang percaya pada anak. Pada pola asuh demokrasi, anak akan menampakkan perilaku moral yang baik sesuai dengan harapan. Hal ini disebabkan adanya kesempatan orang tua dan anak untuk berdiskusi dan adanya perhatian serta penghargaan terhadap hak anak pada pola asuh ini. Setiap larangan kepada anak pada pola asuh ini selalu disertai dengan penjelasan yang dapat dimengerti. Sebaliknya, pola asuh permisif kurang tepat digunakan untuk menanamkan perilaku moral pada anak. Pola asuh ini kurang berperan dalam penanaman etika, karena orang tua beranggapan bahwa perilaku anak yang tidak baik akan berubah seiiring dengan pertambahan usianya karena bertambahnya pengetahuan anak. Pola asuh dalam kaitannya dengan pendidikan karakter tentu saja memiliki peran yang signifikan oleh karena melalui pola asuh, orang tua menanamkan nilai-nilai karakter kepada anak-anak.

Temuan lain oleh Sarwar (2016) mengungkapkan bahwa gaya pengasuhan yang otoriter menyebabkan anak/remaja menjadi nakal, karena kekakuan yang luar biasa yang ditunjukkan oleh orang tua membuat anak suka memberontak. Orang tua yang otoriter cenderung untuk mengendalikan dan menggunakan lebih dari cukup kekuatan untuk perkembangan masa depan anak-anak mereka, tetapi anak-anak remaja menganggapnya negatif karena tindakan mereka dibatasi. Berdasarkan prespektif penelitian tesebut, pengasuhan yang baik adalah demokratis (authoritative) di mana orang tua mengawasi anak-anaknya dan mencoba memahami pola pikir anak-anaknya. Dari temuan tersebut dapat disimpulkan bahwa pola asuh memiliki peran yang sangat penting dalam membentuk perilaku dan karakter anak. Pola asuh itu tidak terjadi dalam sebuah ruang hampa melainkan dalam keluarga yang merupakan lingkungan terdekat anak. Sebagaimana dalam teori ekologi disebutkan bahwa keluarga merupakan lingkungan terdekat anak yang menjadi tempat anak untuk berkembang membentuk pola dan kebiasaan (Santrock, 2012).

Pola dan kebiasaan dapat diciptakan melalui intervensi dan habituasi. Intervensi dilaksanakan melalui penerapan serangkaian kegiatan terstruktur yang dengan sengaja dirancang untuk mencapai tujuan pembentukan karakter (Putry, 2019). Sedangkan habituasi yaitu dengan proses pembiasaan yang diciptakan dan ditumbuhkembangkan dalam situasi dan kondisi yang berisi berbagai penguatan yang memungkinkan anak membiasakan diri berperilaku sesuai dengan nilai yang diharapkan baik di sekolah, di rumah, dan di lingkungan masyarakat. Teori lain yang dapat 
digunakan untuk menerangkan bagaimana perilaku pola dan kebiasaan dibentuk adalah teori behaviorisme. Tondok (2008) menjelaskan bahwa perilaku terkait sampah yang dilakukan oleh masyarakat merupakan hasil dari pembiasaan yang dibentuk lingkungan sekitar. Contoh nyata yang bisa ditemukan dalam kehidupan sehari-hari adalah tidak adanya hukuman konkrit, misalnya ada teguran atau denda terkait perilaku membuang sampah sembarangan baik di fasilitas umum seperti bandara, jalan raya, maupun tempat lainnya. Konsekuensi yang diperoleh masyarakat terkait kegiatan menyampah ini justru hal yang "menyenangkan" bagi mereka, yakni rasa terbebas dari benda kotor yang mengganggu mereka, misalnya tisu bekas atau puntung rokok. Hal ini akan sangat berbeda pada negara yang memberikan konsekuensi tegas pada tindakan ini. Oleh karena itu, perlu adanya penekanan penanaman karakter terkait peduli lingkungan ini sejak dini pada anak. Berdasarkan kajian teori dan hasil-hasil penelitian diatas, maka hipotesis penelitian ini adalah terdapat pengaruh positif yang signifikan pola asuh orang tua terhadap sikap peduli sampah pada anak.

\section{METODE}

Metode penelitian yang digunakan adalah metode survei. Populasi pada penelitian ini adalah empat sekolah dasar yang ada di kecamatan Tobelo Tengah yaitu SD GMIH "X", SD GMIH "Y", SD Inpres "X" Wosia, dan SD Inpres "Y". Selanjutnya untuk menentukan sampel penelitian peneliti menggunakan purposive sampling yakni siswa kelas V dan VI di keempat SD tersebut. Total sampel berjumlah 200 orang siswa.

Selanjutnya, untuk mengumpulkan data penelitian, peneliti menggunakan skala pola asuh dan skala sikap peduli sampah. Skala tersebut disusun menggunakan model Lickert dengan empat pilihan jawaban yakni "Sangat Sesuai", "Sesuai”, "Tidak Sesuai”, dan "Sangat Tidak Sesuai". Setiap item pada skala terdiri dari favorable item dan unfavorable item. Sebelum digunakan pada penelitian, kedua skala tersebut terlebih dahulu diujicobakan untuk mengukur validitas dan reliabilitasnya. Setelah memenuhi standar validitas dan realibilitas, skala tersebut dapat dipakai dalam penelitian. Setelah mengumpulkan data, peneliti kemudian melakukan analisis regresi untuk melihat besarnya pengaruh pola asuh terhadap sikap peduli sampah. Hasil analisis data selanjutnya disajikan secara deskriptif

\section{HASIL DAN PEMBAHASAN}

Sebelum melakukan analisis uij hipotesis penelitian, peneliti terlebih dahulu melakukan uji asumsi. Hasil uji asumsi dan uji hipotesis disajikan sebagai berikut. 


\section{Uji Homogenitas}

Uji ini dilakukan guna mengetahui apakah varians kelompok yang dibandingkan berbeda/heterogen ataukah tidak/homogen. Dan berdasarkan hasil analisis diperoleh data sebagaimana termuat dalam Tabel 1 .

Tabel 1. Hasil Uji Homogenitas Menggunakan Uji Lavene

\begin{tabular}{cccc}
\hline F & df1 & df2 & Sig. \\
\hline 0.795 & 31 & 168 & 0.771 \\
\hline
\end{tabular}

Data pada Tabel 1 menunjukkan bahwa nilai signifikansinya adalah $0.771(\rho>0.05)$, maka dapat dikatakan bahwa varians data pada kedua kelompok data tersebut adalah sama/homogen.

\section{Uji Normalitas}

Uji ini dimaksudkan untuk mengetahui sebaran data penelitian. Berdasarkan uji normalitas dengan menggunakan uji Kolmogorov-Smirnov diperoleh hasil sebagaimana termuat pada tabel 2 .

Tabel 2. Hasil Uji Normalitas Menggunakan Uji One-Sample Kolmogorov-Smirnov

\begin{tabular}{llcc}
\hline & & Pola Asuh & $\begin{array}{c}\text { Sikap Peduli } \\
\text { Sampah }\end{array}$ \\
\hline$N$ & & 200 & 200 \\
Normal Parameters a,b & Mean & 73.86 & 33.87 \\
& Std. Deviation & 6.712 & 4.468 \\
Most Extreme Differences & Absolute & 0.083 & 0.085 \\
& Positive & 0.042 & 0.035 \\
Kolmogorov-Smirnov $Z$ & Negative & -0.083 & -0.085 \\
Asymp. Sig. (2-tailed) & & 1.178 & 1.206 \\
\hline
\end{tabular}

Tabel diatas menunjukkan bahwa variabel pola asuh memiliki nilai K-S Z sebesar 1.178, dan nilai signifikansi sebesar $0.124(\rho>0.05)$. Sedangkan variabel perilaku peduli sampah yang memiliki nilai K-S Z sebesar 1.206 dengan nilai signifikansei 0.109 ( $\rho>0.05)$. Ini berarti bahwa data dalam penelitian ini memenuhi uji normalitas atau terdistribusi normal.

\section{Uji Linearitas}

Uji ini dilakukan untuk mengetahui apakah terdapat hubungan yang linier antara variabel pola asuh dan variabel perilaku peduli sampah. Hasil dari uji ini dapat dilihat pada Tabel 3.

Tabel 3. Hasil Uji Linearitas

\begin{tabular}{|c|c|c|c|c|c|c|c|}
\hline & & & $\begin{array}{l}\text { Sum of } \\
\text { Squares }\end{array}$ & $D f$ & $\begin{array}{l}\text { Mean } \\
\text { Square }\end{array}$ & $F$ & Sig. \\
\hline \multirow{5}{*}{$\begin{array}{l}\text { Sikap Peduli } \\
\text { Sampah * Pola } \\
\text { Asuh }\end{array}$} & \multirow{3}{*}{ Between Groups } & (Combined) & 702.902 & 31 & 22.674 & 1.165 & 0.267 \\
\hline & & Linearity & 137.968 & 1 & 137.968 & 7.087 & 0.009 \\
\hline & & $\begin{array}{c}\text { Deviation } \\
\text { from Linearity }\end{array}$ & 564.933 & 30 & 18.831 & 0.967 & 0.521 \\
\hline & \multicolumn{2}{|c|}{ Within Groups } & 3270.453 & 168 & 19.467 & & \\
\hline & \multicolumn{2}{|c|}{ Total } & 3973.355 & 199 & & & \\
\hline
\end{tabular}


Data Tabel 3 di atas menunjukkan bahwa hubungan kedua variabel adalah linier. Hal tersebut dapat dilihat dari nilai F pada kolom linerity sebesar 7.087 dan berada pada taraf signifikansi 0.009 $(\rho<0.05)$ dan nilai F pada Deviation from linearity sebesar 0.967 dengan nilai signifikansi 0.521 $(\rho>0.05)$.

\section{Uji Hipotesis}

Uji hipotesis pada penelitian ini menggunakan analisis regresi linier sederhana dengan metode Enter untuk melihat tingkat prediksi variabel independen terhadap variabel dependen. Dalam analisis ini, peneliti menetapkan level of significance (taraf signifikansi) sebesar 5\% $(\alpha=0,05)$. Dengan demikian, maka berdasarkan hasil analisis diperoleh data pada Tabel 4.

Tabel 4. Hasil Uji Hipotesis

\begin{tabular}{|c|c|c|c|c|c|}
\hline \multirow{2}{*}{ Model } & \multicolumn{2}{|c|}{ Unstandardized Coefficients } & \multirow{2}{*}{$\begin{array}{c}\text { Standardized } \\
\text { Coefficients }\end{array}$} & \multirow[t]{2}{*}{$t$} & \multirow[t]{2}{*}{ Sig. } \\
\hline & $B$ & Std. Error & & & \\
\hline (Constant) & 24.703 & 3.447 & & 7.166 & 0.000 \\
\hline Pola Asuh & 0.124 & 0.046 & 0.186 & 2.669 & 0.008 \\
\hline
\end{tabular}

Output pada tabel di atas menunjukkan bahwa nilai t sebesar 2.669 dengan taraf signifikansi $0.008(\rho<0.05)$ yang berarti bahwa terdapat pengaruh positif dan signifikan pola asuh orang tua terhadap sikap peduli sampah pada anak. Besarnya pengaruh pola asuh orang tua terhadap sikap peduli sampah dapat dilihat pada nilai R-square yakni sebesar 0.035 atau 3.5\%.

Pola asuh mempunyai pengaruh yang signifikan terhadap sikap peduli sampah. Pengaruhnya adalah $3.5 \%$. Walaupun angka tersebut menunjukkan bahwa pengaruh pola tidak telalu besar akan tetapi signifikan. Artinya, pola asuh tidak bisa diabaikan dalam membentuk sikap anak yang peduli terhadap sampah. Mengingat sikap peduli sampah merupakan salah satu bagian dari nilainilai pendidikan karakter yakni peduli lingkungan, maka penelitian ini selaras dengan hasil penelitian yang dilakukan oleh Simanjuntak (2017) tentang pembentukan karakter. Penelitian tersebut menunjukkan bahwa pola asuh orang tua berpengaruh positif dan signifikan terhadap pembentukan karakter anak. Hasil penelitian yang dilakukan oleh Kilonzo (2017) secara spesifik menjelaskan bahwa penting bagi orang tua mengadopsi pengasuhan otoriter pada anak remaja dalam menetapkan aturan dan pedoman serta menunjukkan sikap kekuasaan dan disiplin sehingga menghasilkan perilaku yang positif. Selain itu, berdasarkan hasil studi literatur, Fimansyah (2019) menyimpulkan bahwa pengasuhan berperan penting dalam membangun karakter anak. Dalam hal ini pengasuhan memiliki pengaruh signifikan dalam mengembangkan karakter anak menjadi baik atau buruk, apakah mereka akan tumbuh menjadi orang yang ekstrovert, introvert, atau ambisius dalam kehidupan sehari-hari mereka.

Loudová dan Lašek (2015) menyatakan bahwa dalam proses pengasuhan tersebut ada hal penting yang aktif dilakukan orang tua yakni melatih anak menginternalisasi norma-norma perilaku sosial dan moral yang nantinya berpengaruh pada perjalanan hidup anaknya. Dalam hal 
ini anak harus dapat bersaksi tentang praktik pendidikan yang tepat dari orang tua terutama dalam berinteraksi dengan masyarakat dan menaati peraturan sehingga anak-anak tersebut mampu menunjukkan bahwa proses pendidikan dari orang tua berhasil. Hal serupa ditegaskan oleh Sumarno (2015) bahwa untuk memiliki sifat kemanusiaannya, anak sangat membutuhkan orang lain dalam perkembangannya, dan orang yang paling bertanggungjawab adalah orang tua.

Dalam kaitannya dengan sikap peduli sampah, orang tua memiliki tanggung jawab dalam mendidik dan mengajarkan anak. Tanggung jawab itu tercermin pada pola pengasuhan yang diterapkan. Baik itu pola asuh otoriter, demokratis maupun permisif. Melalui ketiga jenis pola asuh ini orang tua dapat menanamkan norma-norma dan nilai-nilai karakter yang dapat menjadi pedoman bagi anak dalam berperilaku. Pola asuh juga menjadi sarana bagi agar berperan sebagai role model yang dapat diamati oleh anak (Bornstein, dkk., 2018).

Anak belajar tingkah laku yang ditampilkan melalui pengamatan dalam kehidupan sehari-hari. Bandura (1986) menyebutnya sebagai observational learning atau pembelajaran observasional. Menurut Rosenthal dan Zimmerman (dalam Schunck, 2012), inti dari pembelajaran ini adalah informasi tentang cara-cara menghasilkan perilaku yang baru disampaikan model kepada pengamat. Terlebih jika pemodelan yang dikombinasikan dengan penjelasan lebih efektif dalam mengajarkan keterampilan daripada penjelasan saja.

Terkait dengan sikap peduli terhadap sampah, orang tua dapat menjadi model yang memunculkan perilaku tidak membuang sampah pada sembarang tempat. Disamping itu, orang tua juga memberikan penjelasan kepada anak akan dampak dari lingkungan yang kotor atau sampah yang berserakan. Sehingga melalui kombinasi model dan penjelasan, anak dapat membentuk sikap bahkan perilaku yang sesuai dengan model atau membuang sampah pada tempatnya. Teori lain yang menjelaskan tentang bagaimana membentuk perilaku adalah teori pengkondisian operan yang dikemukakan oleh Skinner (2019). Menurut teori ini perilaku akan terbentuk apabila diberi penguatan dan hukuman. Penguatan positif misalnya dengan memperkuat respons-respons dengan menambahkan konsekuensi-konsekuensi positif seperti pujian atau perhatian. Sedangkan hukuman diberikan untuk menghilangkan sikap-sikap tertentu yang tidak diinginkan (Crain, 2007).

Dalam kaitannya dengan pola asuh, orang tua dapat memberikan penguatan berupa pujian ketika anak membuang sampah pada tempatnya. Sebaliknya, anak akan mendapat hukuman apabila membuang sampah di sembarang tempat. Jadi melalui pola asuh yang di dalamnya terdapat penguatan dan hukuman inilah orang tua dapat membentuk sikap dan perilaku anak. Dengan berpedoman pada teori stimulus - respon, maka sikap peduli sampah pada anak dapat dijelaskan sebagai berikut bahwa sampah dianggap sebagai stimulus (S) yang akan menimbulkan respon/perilaku (R). Keterkaitan langsung antara stimulus dan respon yang diharapkan, dapat digunakan untuk mendorong terbentuknya kebiasaan pada perilaku sehari-hari anak. Misalnya, 
seorang anak dilatih sejak dini oleh orang tuanya untuk membuang barang yang sudah tidak terpakai/barang sisa ke keranjang sampah. Pengalaman yang terjadi secara berulang-ulang, akan melekat menjadi kebiasaan yang terus dipraktekkan ketika ia dewasa (Wibowo, 2009).

Disisi lain, perlu diakui bahwa kecilnya pengaruh pola asuh (3.5\%) terhadap sikap peduli sampah pada anak menunjukkan bahwa sikap peduli sampah pada anak tidak hanya ditentukan oleh pola asuh orang tua melainkan juga oleh faktor lain di luar pola asuh orang tua, misalnya selfawareness, focus of control, tanggung jawab, motivasi, dan faktor-faktor lain yang dapat diteliti lebih lanjut.

\section{SIMPULAN DAN SARAN}

\section{Simpulan}

Hasil penelitian membuktikan bahwa pola asuh secara signifikan berpengaruh terhadap sikap peduli sampah pada anak, walaupun pengaruh tersebut hanya sebesar 3.5\%. akan tetapi signifikansi pengaruh tersebut membuktikan bahwa keberadaan pola asuh di dalam keluarga tidak bisa diabaikan. Melalui pola pengasuhan yang tepat, anak akan belajar menghargai lingkungan sekitar khususnya tidak membuang sampah di sembarang tempat.

\section{Saran}

Melihat pentingnya peran orang tua dalam membentuk sikap dan perilaku anak maka melalui pola asuh yang tepat orang tua dapat membantu anak tumbuh menjadi pribadi yang peduli terhadap lingkungan sekitar melalui sikap dan perilaku atau bahkan kesadaran dalam membuang sampah pada tempatnya.

\section{UCAPAN TERIMA KASIH}

Ucapan terimakasih disampaikan kepada Direktorat Jenderal Penguatan Riset dan Pengembangan, Kementerian Riset, Teknologi, dan Pendidikan Tinggi yang telah mendanai penelitian ini melalui skema Penelitian Dosen Pemula tahun 2019.

\section{DAFTAR RUJUKAN}

Adawiah, R. (2017). Pola Asuh Orang Tua dan Implikasinya terhadap Pendidikan Anak: Studi pada Masyarakat Dayak di Kecamatan Halong Kabupaten Balangan. Jurnal Pendidikan Kewarganegaraan, 7(1), 33-48.

Bandura, A. (1986). Social foundations of thought and action: A social cognitivetheory. New Jersey: Prince-Hall.

Bornstein, M. H., Putnick, D. L., \& Suwalsky, J. T. (2018). Parenting cognitions $\rightarrow$ parenting practices $\rightarrow$ child adjustment? The standard model. Development and psychopathology, 30(2), 399-416.

Crain, W. (2007). Teori perkembangan: Konsep dan aplikasi (terjemahan oleh YudiSantoso). Yogyakarta: Pustaka Pelajar. 
Doinita, N. E. \& Maria, N. D. (2015). Attactment and parenting styles. Procedia-Social and Behavioral Sciences (203),199-204.

Fimansyah, W. (2019). Pengaruh pola asuh orang tua terhadap pembentukan karakter anak di era globalisasi. Primary Education Journal Silampari, 1(1), 1-6.

Hurlock, E. (1999). Psikologi perkembangan suatu pendekatan sepanjang rentang kehidupan. Jakarta: Erlangga.

Jannah, H. (2012). Bentuk pola asuh orang tua dalam menanamkan perilaku moral pada anak usia di kecamatan Ampek Angkek. Pesona PAUD, 1(2).

Kilonzo, P. M. (2017). The impact of parenting styles on personality dimension of adolescents in public secondary schools: a case of Mombasa Country, Kenya. International Journal of Education and Research, 5(7), 263-276.

Loudová, I. \& Lašek, J. (2015). Parenting style and its influence on the personal and moraldevelopment of the child. Procedia-Social and Behavioral Sciences (174), 1247-1254.

Mahendra, Y. (Agustus 2019). Pendidikan Karakter di Sekolah Dasar. Dalam Prosiding Seminar Nasional Pagelaran Pendidikan Dasar Nasional (PPDN) 2019 (Vol. 1, No. 1, 257-266).

Mifbakhuddin, Salawati, T., \& Kasmudi, A. (2010). Gambaran pengelolaan sampah rumah tangga tinjauan aspek pendidikan, pengetahuan, dan pendapatan perkapita di Rt 6 Rw 1 Kelurahan Pedurungan Tengah Semarang. Jurnal Kesehatan Masyarakat Indonesia, 6(1), 1-14.

Peraturan Presiden Republik Indonesia Nomor 87 tahun 2017 Tentang Penguatan Pendidikan Karakter. Jakarta: Lembaran Negara Republik Indonesia Tahun 2017 Nomor 195.

Putry, R. (2019). Nilai Pendidikan Karakter Anak di Sekolah Perspektif Kemendiknas. Gender Equality: International Journal of Child and Gender Studies, 4(1), 39-54.

Santrock, J.W. (2012). Life-Span Development: Perkembangan Masa Hidup Edisi 13. Jilid 1. Jakarta: Erlangga.

Sarwar, S. (2016). Influence of parenting style on children's behaviour. Journal of Education and Educational Development, 3(2), 222-249.

Schunk, D. H. (2012). Learning theories: An educational perspective (6th Ed.).Boston: Allyn \& Bacon.

Simanjuntak, M. (2017). Pengaruh pola asuh orang tua terhadap pembentukan karakter anak. Prosiding Semnastafis Unimed, 1(1), 286-291.

Skinner, B. F. (2019). The behavior of organisms: An experimental analysis. BF Skinner Foundation.

Sumarno. (2015). Model konstruk kecerdasan emosional siswa sd. Sekolah Dasar; Kajian Teori dan Praktik Pendidikan, 24(1) 26-33

Tondok, M. S. (2008). "Menyampah" dari prespektif psikologi. Harian Surabaya Post. Akses tanggal 21 Agustus 2018.

Wibowo, I. (2009). Pola perilaku kebersihan: Studi psikologi lingkungan tentang penanggulangan sampah perkotaan. Makara, Sosial Humaniora, 13(1), 37-47. 